\title{
Evaluation of Promising Sweet potato Clones for Higher Root Yield and Dry Matter Content
}

DOI: $10.18196 /$ pt.v9i1.6026

\author{
Wiwit Rahajeng*, Joko Restuono, Febria Cahya Indriani, Purwono \\ Indonesian Legumes and Tuber Crops Research Institute \\ Jl. Raya Kendalpayak KM 8. Po Box 66 Malang, East Java, 65101, Indonesia \\ *Corresponding author, email: email: wiwit.rahajeng@gmail.com
}

\begin{abstract}
Dry matter content is one of the important characteristics of sweet potatoes in addition to high yield. The aim of this study was to evaluate the performance of promising sweet potato clones for higher root yield and dry matter content. A hundred promising sweet potato clones were evaluated and arranged in randomized block design with two replication. The variables observed included: weight of vine, harvest index, number of root per plot, the weight of root per plot, dry matter content, root yield, root skin color, and flesh color. The analysis of variance showed a significant difference among the tested genotypes in all traits observed. A hundred promising sweet potato clones showed that root yield has varied ranged from 4.88-41.38 $t h^{-1}$ with an average $20.28 \mathrm{t}$ $h^{-1}$ and dry matter content ranged from 19.19-40.65\% with an average 30.47\%. Fifteen promising clones of a hundred clones tested had high root yield and dry matter content with varying color flesh.

Keywords: Ipomoea batatas, Root yield, Promising clones, Root crop
\end{abstract}

\section{ABSTRAK}

Kadar bahan kering umbi merupakan karakteristik penting pada ubi jalar selain hasil umbi. Tujuan dari penelitian ini adalah untuk mengevaluasi keragaan klon-klon harapan ubi jalar untuk hasil dan kadar bahan kering tinggi. Seratus klon harapan ubi jalar dievaluasi dan disusun dalam rancangan acak kelompok dengan dua ulangan. Variabel yang diamati meliputi: bobot sulur, indeks panen, jumlah umbi perplot, bobot umbi perplot, kadar bahan kering, hasil umbi, warna kulit dan warna daging umbi. Analisis ragam menunjukkan perbedaan yang nyata antara genotipe yang diuji pada semua karakter yang diamati. Klon-klon harapan ubi jalar menunjukkan hasil umbi bervariasi antara 4,88 - 41,38 t/ha dengan rata-rata 20,28 t/ha dan kadar bahan kering berkisar antara 19,19 - 40,65\% dengan rata-rata 30,47\%. Lima belas klon harapan dari seratus klon yang diuji memiliki hasil umbi dan kadar bahan kering yang tinggi dengan warna daging umbi yang bervariasi.

Kata Kunci: Ipomoea batatas, Hasil umbi, Klon harapan, Tanaman akar

\section{INTRODUCTION}

Sweet potato (Ipomoea batatas) is a root crop which become one of the important food sources in Indonesia. In Indonesia, sweet potato as a food source ranks fourth after rice, corn and cassava commodities (Ambarsari et al. 2009). Flour has a considerable potential to be developed to support the diversification of non-rice food programs. Beside functions as a food source, it can be used as industrial raw materials, feed and renewable energy resources (Vimala et al. 2012; Waluyo et al. 2015; Pedrosa et al. 2015). Sweet potato is also rich of carbohydrate and nutrition content such as protein, dietary fiber, minerals (iron, calcium, potassium, phosphorus, and sodium), vitamins (vitamin C, vitamin B1, and vitamin B2) as well as bioactive compounds such as carotenoids, anthocyanins, and phenylpropanoids (Mohanraj and Sivasankar 2014; Shekhar et al., 2015; Pradhan et al., 2015).
The varied use of sweet potato for food sources and industrial materials causes the increase of sweet potato needs. Increased demand for sweet potatoes needs to be supported by increased productivity of sweet potatoes. Currently, the national average productivity of sweet potatoes is 18.02 t.ha $^{-1}$ (Statistics Indonesia, 2017). This value is below the potential yield of some of the superior varieties that have been released. Based on the description of sweet potato varieties (Balitkabi 2016), the productivity of superior sweet potato varieties can reach 25-30 $t \mathrm{ha}^{-1}$. Therefore the productivity of sweet potato still has to be improved. One of the efforts to fulfill the increasing needs of sweet potato is by genetic improvement through the breeding program, especially with high yield potency.

Beside high yield potency, the good quality of tubers was also one important thing in the breeding 
program (Khayatnezhad et al., 2011; Rahman et al., et al., 2011; Mbah and Eke-Okoro, 2015).

2013). Dry matter content is one of the important Many breeding programs had been conducted characteristics of sweet potatoes in addition to high to develop varieties of high yield potency and dry yield. Mbah and Eke-Okoro (2015) mentioned that matter content (Vimala and Hariprakash 2011; for farmers and industry, the dry matter content Cervantes-Flores et al. 2011; Shumbusha et al. is an essential economic value for sweet potato 2014; Waluyo et al. 2015; Mbah and Eke-Okoro products, which is the chemical potential of crops 2015). Baafi et al. (2017) conducted a diallel cross to and reflects its true biological yields. Mohammed et get tuber varieties with those criteria. Kathabwalika al. (2009) stated that the dry matter content is also et al. (2016) got eight promising sweet potato clones one of the essential criteria in breeding programs, with high yield potency and dry matter content. dry matter production is an important indicator for This study aimed to evaluate the performance of root yield. High dry matter content is vital for the promising sweet potato clones for higher root yield processing industry and associated with consumer and dry matter content. So that from this research preferences (Placide et al. 2013; Shumbusha et al. it is hoped that some promising clones can be re2014; Ngailo et al. 2015). Several studies stated that leased into sweet potato varieties with higher root consumers and industry prefer sweet potato variet- yields and dry matter content.

ies with high dry matter content (Cervantes-Flores

Table 1. List of promising sweet potato clones used in this study

\begin{tabular}{|c|c|c|c|c|c|c|c|}
\hline No. & Genotype & No. & Genotype & No. & Genotype & No. & Genotype \\
\hline 1. & MSU 15001-05 & 26. & MSU 15008-69 & 51. & MSU 15013-39 & 76. & MSU 15016-92 \\
\hline 2. & MSU 15001-01 & 27. & MSU 15008-07 & 52. & MSU 15013-44 & 77. & MSU 15016-97 \\
\hline 3. & MSU 15004-04 & 28. & MSU 15009-01 & 53. & MSU15013-49 & 78. & MSU 15016-98 \\
\hline 4. & MSU 15005-03 & 29. & MSU 15009-04 & 54. & MSU 15013-05 & 79. & MSU 15016-108 \\
\hline 5. & MSU 15006-01 & 30. & MSU 15009-05 & 55. & MSU 15013-56 & 80. & MSU 15016-113 \\
\hline 6. & MSU 15007-08 & 31. & MSU 15009-07 & 56. & MSU 15013-62 & 81. & MSU 15016-126 \\
\hline 7. & MSU 15007-15 & 32. & MSU 15009-12 & 57. & MSU 15013-69 & 82. & MSU 15016-134 \\
\hline 8. & MSU 15007-28 & 33. & MSU 15009-13 & 58. & MSU 15014-01 & 83. & MSU 15017-06 \\
\hline 9. & MSU 15007-29 & 34. & MSU 15009-22 & 59. & MSU 15014-02 & 84. & MSU 15017-28 \\
\hline 10. & MSU 15007-35 & 35. & MSU 15009-23 & 60. & MSU 15014-01 & 85. & MSU 15018-03 \\
\hline 11. & MSU 15007-36 & 36. & MSU 15009-25 & 61. & MSU 15014-11 & 86. & MSU 15018-01 \\
\hline 12. & MSU 15007-39 & 37. & MSU 15009-27 & 62. & MSU 15016-01 & 87. & MSU 15018-14 \\
\hline 13. & MSU 15007-41 & 38. & MSU 15009-28 & 63. & MSU 15016-03 & 88. & MSU 15018-19 \\
\hline 14. & MSU 15007-42 & 39. & MSU 15011-03 & 64. & MSU 15016-17 & 89. & MSU 15018-22 \\
\hline 15. & MSU15008-06 & 40. & MSU 15011-08 & 65. & MSU 15016-23 & 90. & MSU 15018-39 \\
\hline 16. & MSU15008-11 & 41. & MSU 15011-09 & 66. & MSU 15016-24 & 91. & MSU 15018-53 \\
\hline 17. & MSU15008-16 & 42. & MSU 15012-08 & 67. & MSU 15016-36 & 92. & MSU 15018-55 \\
\hline 18. & MSU15008-02 & 43. & MSU 15013-06 & 68. & MSU 15016-38 & 93. & MSU 15019-07 \\
\hline 19. & MSU15008-22 & 44. & MSU 15013-01 & 69. & MSU 15016-49 & 94. & MSU 15019-24 \\
\hline 20. & MSU15008-23 & 45. & MSU 15013-21 & 70. & MSU 15016-54 & 95. & MSU 15019-26 \\
\hline 21. & MSU15008-29 & 46. & MSU 15013-22 & 71. & MSU 15016-61 & 96. & MSU 15019-31 \\
\hline 22. & MSU 15008-33 & 47. & MSU 15013-23 & 72. & MSU 15016-67 & 97. & MSU 15019-40 \\
\hline 23. & MSU 15008-36 & 48. & MSU 15013-24 & 73. & MSU 15016-69 & 98. & MSU 15019-44 \\
\hline 24. & MSU 15008-48 & 49. & MSU 15013-28 & 74. & MSU 15016-78 & 99. & Sari \\
\hline 25. & MSU 15008-52 & 50. & MSU 15013-35 & 75. & MSU 15016-09 & 100. & Cilembu \\
\hline
\end{tabular}




\section{MATERIALS AND METHODS}

The research was conducted in Maret - August 2016 at Tumpang, Malang, East Java, Indonesia. A hundred sweet potato promising clones were evaluated and arranged in a randomized block design with two replication. The list of sweet potato promising clones used in this study was presented in Table 1. Each genotype was planted on a $1 \mathrm{~m}$ wide $\mathrm{x} 5 \mathrm{~m}$ long plot with the spacing between rows and plants was $100 \mathrm{~cm} \times 25 \mathrm{~cm} .2 / 3$ dose of fertilizer (300 kg/ha NPK Phonska) was applied at planting, and the remaining was applied 5 weeks after planting. Weeding was done at 4, 7, and 10 weeks after planting. Earthing down was done at 4 weeks after planting, earthing up was done at 7 or 8 weeks after planting. Irrigation, pest, and disease control were applied as needed.

Sweet potato clones harvested and evaluated at five months after planting. The variables observed included: weight of vine, harvest index, number and weight of root per plot, dry matter content, root yield, root skin and flesh color. Analysis of variance using PKBT-STAT 2.1 was conducted to determine the variability of each character. Least significant differences (LSD) at 5\% level of probability were used to detect differences between means.

\section{RESULTS AND DISCUSSION}

The result of the variance analysis for all the traits tested is shown in Table 2. The performance of all tested accessions statistically was highly significant $(P<0.01)$ in weight of vine, number and weight of root per plot, harvest index, root yield, and dry matter content. Indicated that each accession used has a different genetic nature, and gives a significant influence on growth and yield, especially for the six traits. Gebremeskel et al. (2018) added there is also a high variability in the accessions used.

Descriptive statistics of the weight of vine, number and weight of root per plot, harvest index,
Table 2. Analysis of variance sweet potato promising clones

\begin{tabular}{lcccc}
\hline \multirow{2}{*}{ Characters } & \multicolumn{3}{c}{ Mean } & \multirow{2}{*}{ CV(\%) } \\
\cline { 2 - 5 } & Block & Genotype & Error \\
\hline Weight of vine & $4.74^{*}$ & $9.64^{* *}$ & 0.88 & 20.31 \\
Number of root perplot & $103.68 \mathrm{~ns}$ & $504.04^{* *}$ & 37.36 & 13.90 \\
Weight of root perplot & $27.18^{* *}$ & $28.43^{* *}$ & 2.21 & 17.12 \\
Harvest index & $0.07^{* *}$ & $0.03^{* *}$ & 0.01 & 12.34 \\
Root yield & $125.88^{* *}$ & $122.34^{* *}$ & 10.13 & 15.70 \\
Dry matter content & $0.01 \mathrm{~ns}$ & $34.52^{* *}$ & 0.09 & 0.96 \\
\hline
\end{tabular}

Note: ${ }^{*}$ significant at $\mathrm{p}<0.01, \mathrm{~ns}=$ non significant

Table 3. Descriptive statistics of sweet potato promising clones quantitative traits

\begin{tabular}{lcccc}
\hline Characters & Mean & StDev & Min & Max \\
\hline Weight of vine & 4.62 & 2.20 & 1.80 & 12.35 \\
Number of root perplot & 43.96 & 15.88 & 9.00 & 96.00 \\
Weight of root perplot & 8.69 & 3.77 & 0.98 & 18.16 \\
Harvest index & 0.66 & 0.13 & 0.32 & 0.88 \\
Root yield & 20.28 & 7.82 & 4.88 & 41.38 \\
Dry matter content & 30.47 & 4.15 & 19.19 & 40.65 \\
\hline
\end{tabular}

root yield, and dry matter content of the sweet potato promising clones are presented in Table 3. The result of the vine weight which is varied can be caused by environment factor or the effect of genetic factor of each observed clone. Then, the vine weight/plot and the root weight/plot will be used for calculating the harvest index. The total and the weight of roots have important role in deciding the tuber yield. The more roots and the heavier the root weight, the higher the root yield. The harvest index of the observed clones shows quite vary numbers, the harvest index can be seen from the vine weight and the tuber weight (Suminarti and Susanto, 2015; Nwankwo et al., 2018). The harvest index is the ratio between the tuber weight and the assimilate total. Clones with high tuber yield generally have high harvest index. It shows that those clones have high efficiency in using assimilate in the root formation process. Prabawardani (2008) also stated the same thing that the higher the harvest index, the more assimilate is used in the root formation. 
According to Vimala dan Hariprakash (2011), the varied yield of the root yield and the dry matter content is affected by many factors, such as: varieties, location, climate, pests, diseases, and the breeding system. In the sweet potato selection, beside the root yield, the dry matter content is also one important criteria. The dry matter content can be used as the root quality indicator. Kathabwalika et al. (2013), mentioned that in sweet potato production, dry matter content is a property most preferred by consumers and an important quality parameter as it indicates mealiness in the roasted or boiled sweet potato. The farmer preference of the root dry matter content is $>25 \%$ (Mbah and Eke-Okoro, 2015). Meanwhile, for industry, the root dry matter content is $>30 \%$ (Rukundo et al. 2013). The information of the root dry matter content is important because it can be used as the indicator of the starch content, $70 \%$ of the main composer of the root dry matter content is starch (Ginting et al. 2012).
Based on the criteria of root yield and dry matter content, there are 15 clones with high yield potency and high dry matter content ( $>25 \mathrm{t} /$ ha dan $>30 \%$ ). Those clones have varied morpho-agronomy (Table 4). Beside of having high root yield and dry matter content, the 15 clones also have high harvest index $(0.51-0.88)$. The color of root skin is mostly red with varied intensity, the rests are beige and orange, while the flesh colors are white, yellow, orange, and purple. Clone MSU 15011.09 has the highest root yield which is $41.38 \mathrm{t} \mathrm{ha}^{-1}$, the dry matter content is $30.24 \%$, and the harvest index is 0.61 . The highest dry matter content is shown by clone MSU 15016.126, with the root yield of $28.62 \mathrm{t} \mathrm{ha}^{-1}$ and the harvest index of 0.82 . This result shows that the 15 clones are selected from 100 observed clones to be continued to the next step of varieties assemble (the yield potency test to the multi-location test). Those clones have possibility to be proposed in the varieties release with the purpose of high yield and dry matter content.

Table 4. The appearance of selected clones based on root yield and dry matter content criteria

\begin{tabular}{llcccccccc}
\hline No. & Genotipe & $\begin{array}{c}\text { Weight of } \\
\text { vine }(\mathrm{kg})\end{array}$ & $\begin{array}{c}\text { Number of } \\
\text { root per plot }\end{array}$ & $\begin{array}{c}\text { Weight of root } \\
\text { per plot }(\mathrm{kg})\end{array}$ & $\begin{array}{c}\text { Harvest } \\
\text { index }\end{array}$ & $\begin{array}{c}\text { Root yield } \\
(\mathrm{t} \mathrm{ha-1})\end{array}$ & $\begin{array}{c}\text { Dry matter } \\
\text { content (\%) }\end{array}$ & \multicolumn{2}{c}{ Root color } \\
\hline 1. & MSin 15011-09 & 6.55 & 43.00 & 13.01 & 0.61 & 41.38 & 30.24 & M5 & K1 \\
2. & MSU 15009-05 & 3.45 & 69.50 & 14.33 & 0.83 & 37.14 & 31.59 & 04 & 04 \\
3. & MSU 15007-41 & 11.35 & 54.00 & 14.83 & 0.51 & 37.08 & 30.44 & M4 & K1 \\
4. & MSU 15016-92 & 3.05 & 32.00 & 12.88 & 0.82 & 34.67 & 32.17 & M5 & P \\
5. & MSU 15008-07 & 5.10 & 39.50 & 13.01 & 0.68 & 32.52 & 32.88 & M5 & K1 \\
6. & MSU 15016-69 & 3.05 & 55.50 & 13.89 & 0.83 & 32.41 & 30.74 & Krem & K3 \\
7. & MSU 15001-05 & 8.95 & 59.00 & 13.44 & 0.63 & 31.35 & 31.22 & M5 & K30 \\
8. & MSU 15016-126 & 2.00 & 29.00 & 12.27 & 0.82 & 28.62 & 34.48 & M1 & K02 \\
9. & MSU 15013-22 & 3.25 & 96.00 & 16.69 & 0.84 & 27.94 & 33.68 & M6 & K2 \\
10. & MSU 15018-14 & 3.95 & 59.00 & 13.54 & 0.78 & 27.87 & 33.30 & M5 & U3 \\
11. & MSU 15016-17 & 3.50 & 50.50 & 9.53 & 0.75 & 27.80 & 34.31 & M6 & K302 \\
12. & MSU 15009-25 & 6.05 & 62.50 & 13.92 & 0.67 & 25.70 & 33.13 & Krem & 05 \\
13. & MSU 15016-108 & 2.80 & 57.50 & 10.99 & 0.81 & 25.64 & 31.48 & M5 & P \\
14. & MSU15008-11 & 1.80 & 34.50 & 8.64 & 0.80 & 25.20 & 32.20 & Krem & K3 \\
15. & MSU 15018-03 & 2.10 & 51.50 & 13.58 & 0.88 & 25.01 & 31.41 & M5 & P \\
\hline
\end{tabular}

Note: $\mathrm{M}=$ red, $\mathrm{Krem}=$ cream $\mathrm{O}=$ orange, $\mathrm{K}=$ yellow, $\mathrm{P}=$ white, $\mathrm{U}=$ purple 


\section{CONCLUSION}

Based on the above discussion, it can be concluded that the analysis of variance showed the significant difference among the tested genotypes in all traits observed. The descriptive analysis showed that root yield have varied ranged from $4.88-41.38 \mathrm{t} \mathrm{h}^{-1}$ with an average $20.28 \mathrm{t} \mathrm{h}^{-1}$ and dry matter content ranged from 19.19 - 40.65\% with an average $30.47 \%$. Fifteen promising clones of a hundred clones tested had high root yield and dry matter content with varying color flesh (white, yellow, orange and purple). It is expected that high yields and high dry matter content characters of the fifteen clones can be stable at the next selection stage. So the clones can be proposed as high yields and high dry matter content varieties.

\section{REFERENCES}

Ambarsari I., Sarjana, \& Choliq A. (2009). Rekomendasi dalam Penetapan Standar Mutu Tepung Ubi Jalar. Balai Pengkajian Teknologi Pertanian. Jawa Tengah.

Baafi E., Gracen V.E., Manu-Aduening J., Blay E.T., Ofori K., \& Carey E.E. (2017). Genetic control of dry matter, starch and sugar content in sweet potato, Acta Agriculturae Scandinavica, Section B-Soil \& Plant Science, 67(2): 110-118 https://doi.org/10.1080/090 64710.2016.1225813

[BALITKABI] Balai Penelitian Tanaman Aneka Kacang dan Umbi. (2016). Deskripsi Varietas Unggal Tanaman Aneka Kacang dan Umbi. Badan Penelitian dan Pengembangan Pertanian.

Cervantes-Flores, J.C., Sosinski B., Pecota K.V., Mwanga R.O.M. \& Catignani G.L. (2011). Identification of quantitative trait loci for dry-matter, starch and $\square$-carotene content in sweet potato. Mol. Breed., 28: 201-216

Gebremeskel H., Jaleto K., Biratu W., \& Abebe H. (2018). Growth and Yield Response of Sweet Potato (Ipomoea batatas L. Lam) Varieties to Lowland Agro-Ecology of Raya Azebo, Ethiopia. Agriculture and Food Sciences Research, 5(2): 52-56.

Ginting E., Utomo J. S., \& Jusuf M. (2012). Identifikasi sifat fisik, kimia dan sensoris klon-klon harapan ubi jalar kaya beta karoten. dalam Pros. Seminar Nasional. (Eds). Rahmianna, A.A., Yusnawan E., Taufiq A., Sholihin, Suharsono, Sundari T., Hermanto. Balai Penelitian Tanaman Aneka Kacang dan Umbi, 612-623.

Kathabwalika D.M., Chilembwe E.H.C., Mwale V.M., Kambewa D., \& Njoloma J.P. (2013). Plant growth and yield stability of orange fleshed sweet potato (Ipomoea batatas) genotypes in three agro-ecological zones of Malawi. Int. Res. J. Agric. Sci. Soil Sci. 3(11), 383-39.
Kathabwalika D.M., Chilembwe E.H.C. \& Mwale V.M. (2016). Evaluation of dry matter, starch and beta-carotene content in orangefleshed sweet potato (Ipomoea batatas L.) genotypes tested in three agro-ecological zones of Malawi, African Journal of Food Science 10(11), 320-326.

Khayatnezhad M., Shahriari R., Gholamin R., Jamaati-e-Somarin S., \& Zabihi-e-Mahmoodabad R. (2011). Correlation and Path Analysis Between Yield and Yield Components in Potato (Solanum tubersum L.). Middle-East Journal of Scientific Research, 7(1), 17-21.

Mbah E.U. \& Eke-Okoro O. (2015). Relationship Between some Growth Parameters, Dry Matter Content and Yield of Some Sweet Potato Genotypes Grown under Rainfed Weathered Ultisols in the Humid Tropics. Journal of Agronomy, 14(3), 121-129.

Mohammed, M.A.H., A.A. Alsadon \& M.S. AL-Mohaidib, (2009). Corn and potato starch as an agar alternative for Solanum tuberosum micropropagation. Afr. J. Biotechnol., 8, 9199-9203.

Mohanraj, R. \& Sivasankar, S. (2014). Sweet potato (Ipomoea batatas [L.] Lam)-a valuable medicinal food: a review. J. Med. Food 17, 733-741.

Ngailo S., Shimelis H., Sibiya J., \& Mtunda K. (2015). Screening of Tanzanian sweet potato germplasm for yield and related traits and resistance to sweet potato virus disease. Acta Agriculturae Scandinavica, Section B-Soil \& Plant Science http://dx.doi.org/ 10.1080/09064710.2015.1063684

Nwankwo I.I.M., Akinbo O.K., Ikoro A.I., Orji N.A.C. \& Njoku T.C. (2018). Evaluation of selected sweet potato landraces for high harvest index and high root yield indices for parental selection. International Journal of Agricultural Policy and Research, 6(7), 90-97. https://www.journalissues.org/IJAPR/ https://doi. org/10.15739/IJAPR.18.011

Pedrosa C.E., Andrade Júnior V.C., Pereira R.C., Dornas M.F.S., Azevedo A.M., \& Ferreira M.A.M. (2015). Yield and quality of wilted sweet potato vines and its silages. Horticultura Brasileira 33: 283-289. DOl: http://dx.doi.org/10.1590/S0102053620150000300002

Placide R., Hussein S., Mark L., \& Daphrose G. (2013). Storage root formation, dry matter synthesis, accumulation and genetics in sweet potato. Australian Journal of Crop Science, 7, 2054-2061.

Prabawardani S., Sarungallo A., Mustamu Y., \& Luhulima F. (2008). Tanggap Klon Lokal Ubi Jalar Papua terhadap Cekaman Kekeringan. Jurnal Penelitian Pertanian Tanaman Pangan, 27(2), 113-119.

Pradhan D.M.P., Mukherjee A., George J., Chakrabarti S.K.,Vimala B., Naskar S.K., Sahoo B. K., \& Samal S. (2015). High starch, beta carotene and anthocyanin rich sweet potato: ascent to future food and nutrition security in coastal and backward areas. Intl J Trop Agric, 33(2), 397- 400 (Part I).

Rahman M.H., Alam Patwary M.M., Barua H., Hossain M. \& Nahar S. (2013). Evaluation of Orange Fleshed Sweet Potato (Ipomoea batatas L.) Genotypes for Higher Yield and Quality. The Agriculturists, 11(2), 21-27.

Rukundo P., Shimelis H., Laing M., \& Gahakwa D. (2013). Storage root formation, dry matter synthesis, accumulation and genetics in sweet potato. AJCS, 13, 2054-2061. 
Shekhar, S., Mishra, D., Buragohain, A. K., Chakraborty, S. \& Chakraborty, N. (2015). Comparative analysis of phytochemicals and nutrient availability in two contrasting cultivars of sweet potato (Ipomoea batatas L.). Food Chem, 173, 957-965.

Shumbusha D., Tusiime G., Edema R., Gibson P., Adipala E., \& Mwanga R.O.M. (2014). Inheritance of root dry matter content in sweet potato. African Crop Science Journal, 22(1), 69-78. URL: http://www.ajol.info/index.php/acsj/article/ view/101373/90563

Statistics Indonesia. (2017). Indikator Pertanian 2017. $152 \mathrm{hlm}$.

Suminarti N.E. \& Susanto. (2015). Pengaruh Macam Dan Waktu Aplikasi Bahan Organik Pada Tanaman Ubi Jalar (Ipomoea batatas L.) Var. Kawi Effect Of Kind And Application Time Of Organic Matter On Sweet Potato (Ipomoea batatas L.) Var. Kawi. Jurnal Agro, 2(1), 15-28

Vimala B. \& Hariprakash B. (2011). Variability of morphological characters and dry matter content in the hybrid progenies of sweet potato (Ipomoea batatas (L) Lam). Gene Conserve, 10, 65-86.

Vimala B., Sreekanth A., Hariprakash B., \& Wolfgang G. (2012). Variation in Morphological Characters and Storage Root Yield among Exotic Orange-Fleshed Sweet Potato Clones and their Seedling Population. Journal of Root Crops, 38(1), 32-37.

Waluyo B., Roosda A.A., Istifadah N., Ruswandi D., \& Karuniawan A. (2015). Identification of Fifty Sweet potato (Ipomoea batatas (L.) Lam.) Promising Clones for Bioethanol Raw Materials. Energy Procedia, 65, 22 - 28 